\title{
PENGARUH STATUS MEROKOK TERHADAP KEMAMPUAN KOGNITIF SESEORANG: STUDI KASUS INDONESIAN FAMILY LIFE SURVEY (IFLS)
}

\author{
THE EFFECTS OF SMOKING STATUS ON A PERSON'S COGNITIVE \\ ABILITIES: THE CASE STUDY OF INDONESIAN FAMILY LIFE \\ SURVEY (IFLS)
}

\author{
Dharra Widdhyaningtyas Mahardhika ${ }^{1 *}$, Zaki Intan Cindyagita ${ }^{1}$, Mochamad Thoriq Akbar ${ }^{1}$, \\ Estro Dariatno Sihaloho ${ }^{1}$ \\ ${ }^{1}$ Department of Economics, Padjadjaran University \\ *dharra16001@mail.unpad.ac.id
}

\begin{abstract}
Abstrak
Merokok merupakan salah satu masalah kesehatan terbesar di Indonesia. Salah satu masalah yang ditimbulkan akibat merokok ialah penurunan kemampuan kognitif seseorang. Jumlah perokok di Indonesia selalu meningkat dari tahun ke tahun. Menurut data Riset Kesehatan Dasar (Riskesdas) tahun 2018, jumlah persentase perokok berusia di atas 15 tahun adalah 33,8\% dengan 62,9\% dari perokok tersebut merupakan laki-laki dan 4,8\% dari perokok tersebut merupakan perempuan. Penelitian ini bertujuan untuk menganalisis seberapa besar pengaruh status merokok terhadap kemampuan kognitif seseorang. Penulis menggunakan data longitudinal dari Indonesian Family Life Survey (IFLS) dan mengikuti data 7.970 individu yang berusia 15 tahun ke atas dari tahun 2007 (IFLS 4) hingga tahun 2014 (IFLS 5). Menggunakan regresi data panel dengan model random effect dan mengontrol karakteristik sosioekonomi serta pengaruh tren, hasil penelitian menunjukkan bahwa menjadi seorang perokok berpengaruh negatif dan signifikan terhadap kemampuan kognitif seseorang. Hasil penelitian juga menunjukkan bahwa menjadi seorang perokok berasosiasi dengan tingkat kognitif yang lebih rendah sebesar 0,1 Standar Deviasi (SD) dibandingkan dengan bukan perokok. Ketika status merokok dipecah berdasarkan tingkat adiksi (yakni perokok ringan, menengah, dan berat), efek penurunan tingkat kognitif menjadi semakin besar secara berurutan 0,08, 0,11, dan 0,25 SD.
\end{abstract}

Kata Kunci: kemampuan kognitif, status merokok, IFLS

Klasifikasi JEL: I12, I18, D12

\begin{abstract}
Smoking is one of the biggest health problems in Indonesia. One of the problems caused by smoking is a decrease in one's cognitive abilities. The number of smokers in Indonesia is always increasing from year to year. According to the Basic Health Research (Riskesdas) data in 2018, the number of smokers aged over 15 years old was $33.8 \%$ with the $62.9 \%$ of smokers being men and $4.8 \%$ of smokers being female. This research aims to analyze how much influence smoking status has on a person's cognitive abilities. The authors use longitudinal data from the Indonesian Family Life Survey (IFLS), which follows data from 7,970 individuals aged 15 and over from 2007 (IFLS 4) to 2014 (IFLS 5). Using panel data regression with a random effect model and controlling for socioeconomic characteristics and trends effect, the results show that being a smoker has a negative and significant effect on a person's cognitive abilities. The results also show that being a smoker is associated with lower cognitive levels of 0.1 Standard Deviation (SD) compared to nonsmokers. When the smoking status was broken down according to the level of addiction (namely light, medium, and heavy smokers), the effects of cognitive decline became bigger, respectively $0.08,0.11$, and $0.25 S D$.
\end{abstract}

Keywords: cognitive ability, smoking status, IFLS

JEL Classification: I12, I18, D12 


\section{PENDAHULUAN}

Kebiasaan merokok merupakan salah satu penyebab dari berbagai masalah kesehatan di dunia. WHO (2020) mengemukakan bahwa terdapat 1,3 milyar penduduk di dunia yang merupakan perokok dan setiap tahunnya terdapat sekitar 8 juta orang mati karena paparan rokok, baik itu perokok aktif maupun perokok pasif. Selain jumlah kematian yang tinggi akibat rokok, Goodchild et al. (2018) menyampaikan bahwa rokok memberikan beban pengeluaran kesehatan yang sangat besar yakni hampir $6 \%$ dari pengeluaran kesehatan global atau sebesar 467 miliar US Dollar dihabiskan untuk pengeluaran kesehatan rokok. Selain itu, biaya ekonomi yang dikeluarkan hampir 2\% dari PDB (Produk Domestik Bruto) dunia atau setara dengan 1,852 miliar US dollar.

Berdasarkan data WHO (2020), sekitar $80 \%$ dari total perokok dunia hidup di negara yang berpenghasilan rendah dan menengah serta 226 juta diantaranya merupakan orang miskin. Indonesia merupakan salah satu negara dengan jumlah perokok terbanyak di dunia, yakni 1 dari 3 orang merupakan seorang perokok atau $39,90 \%$ dari total penduduk di Indonesia merupakan perokok pada tahun 2020. Angka ini menempatkan Indonesia sebagai negara dengan jumlah perokok terbanyak se-Asia Tenggara dan peringkat ke-7 di dunia (Katadata, 2019; World Population Review, 2020). Selain berdampak buruk bagi perekonomian melalui beban pengeluaran kesehatan yang tinggi, rokok dapat mengakibatkan penurunan kualitas Sumber Daya Manusia (SDM) di suatu negara melalui munculnya berbagai penyakit kronis seperti stroke dan tuberkulosis (Davies et al., 2006; Leung et al., 2003; Newcomb \& Carbone, 1992; Shah \& Cole, 2010; Shinton \& Beevers, 1989), serta pelemahan atau penurunan psikis seseorang, termasuk penurunan fungsi kognitif otak (Carmelli, Swan, Reed, Schellenberg, \& Christian, 1999; Cervilla, Prince, \& Mann, 2000).

Sumber Daya Manusia (SDM) yang unggul merupakan salah satu target yang ingin dicapai semua negara. Ketika SDM suatu negara unggul, maka daya saing yang dimiliki akan lebih tinggi dan menurut endogenous growth theory, hal itu merupakan salah satu faktor penting yang menentukan pertumbuhan ekonomi suatu negara (Romer, 1994). Untuk kasus Indonesia yang memiliki jumlah penduduk terbanyak ke-4 di dunia, kualitas SDM yang dimiliki tidak sejalan dengan jumlah penduduk. Berdasarkan Global Competitiveness Index 2019, sebuah indeks yang mengukur tingkat daya saing suatu negara, Indonesia berada pada urutan ke-50 dari 142 negara, merupakan penurunan dari tahun sebelumnya (ke-45) serta berada di urutan ke-4 di ASEAN, berada di bawah Singapura (ke-1), Malaysia (ke-27), dan Thailand (ke-40) (Schwab, 2019). Selain itu, beradasarkan laporan asesmen Programme for International Student Assessment (PISA), sebuah penilaian berkala kepada siswa berumur 15 tahun meliputi kemampuan literasi, matematika, dan sains yang dilaksanakan oleh Organization for Economic Co-operation and Development (OECD), dari 79 negara yang berpartisipasi di tahun 2018, Indonesia berada pada urutan ke-72 dikemampuan membaca dan matematika, dan ke-70 pada kemampuan sains (OECD, 2018).

Data-data tersebut menunjukkan bahwa kualitas SDM Indonesia masih tergolong rendah, bahkan dibandingkan beberapa negara ASEAN lainnya. Salah satu yang mungkin menjadi faktor penyebabnya ialah jumlah penggunaan rokok yang banyak. Bahkan, menggunakan data Riset Kesehatan Dasar (Riskesdas) lebih dari 70\% total perokok di Indonesia pada tahun 2013 masih berumur di bawah 20 tahun. Hal ini dapat berpengaruh negatif, yang mana merokok dapat membuat penipisan pada korteks selebral yang merupakan bagian otak yang sangat krusial untuk kemampuan berpikir meliputi kemampuan daya ingat dan kemampuan belajar (Karama et al., 2015). Berbagai penelitian empiris menemukan bahwa status merokok ataupun kebiasaan sering merokok dapat diasosiasikan dengan kemampuan kognitif yang lebih lemah jika dibandingkan dengan kelompok bukan perokok ataupun mantan perokok (Corley, Gow, Starr, \& Deary, 2012; Richards, Jarvis, Thompson, \& Wadsworth, 2003; Sabia, Marmot, Dufouil, \& Singh-Manoux, 2008).

Berdasarkan hal-hal yang telah dipaparkan di atas, dapat dikatakan bahwa rokok selain membebankan secara ekonomi juga dapat berdampak pada berbagai masalah kesehatan 
termasuk penurunan kemampuan kognitif yang mana secara makro mengakibatkan penurunan kualitas SDM. Menurunnya kualitas SDM yang disebabkan dari terganggunya kesehatan banyak masyarakat akibat rokok, dapat menyebabkan pertumbuhan ekonomi suatu negara menurun dan tidak bisa mencapai potensinya (Bloom, Canning, \& Sevilla, 2004). Walaupun sudah terdapat beberapa penelitian yang membahas hubungan antara kebiasaan merokok dan kemampuan kognitif seseorang, masih sedikit penelitian yang menggunakan sampel studi di Indonesia yang merupakan salah satu negara dengan jumlah perokok terbanyak di dunia. Penelitian ini berusaha mengisi kekosongan tersebut dengan menggunakan data Indonesian Family Life Survey (IFLS) yang merupakan survei sosioekonomi berskala besar yang dilakukan di Indonesia. Diharapkan, penelitian ini dapat menjadi sumber informasi, meningkatkan kesadaran terkait dampak menjadi pecandu rokok terhadap kemampuan kognitif seseorang, serta mengadvokasi pola hidup yang lebih sehat bagi masyarakat.

\section{TINJAUAN LITERATUR}

Rokok menimbulkan banyak kerugian bagi penggunanya (Bergen \& Caporaso, 1999). Penggunaan rokok tetap menjadi penyebab utama penyakit yang dapat dicegah sekaligus penyebab kematian dini terbesar di banyak negara (Benowitz, 2010). Terdapat kemungkinan sebesar $50 \%$ bagi perokok seumur hidup yang meninggal sebelum waktunya akibat komplikasi penyakit dari rokok (Doll, Peto, Boreham, \& Sutherland, 2004). Fakultas Kesehatan Harvard University memproyeksikan bahwa angka kematian dan angka kesakitan akan meningkat hampir tiga kali lipat dalam 25 tahun akibat penggunaan tembakau (Murray \& Lopez, 1997). Selain itu, penggunaan rokok menjadi salah satu penyebab terbesar penyakit kanker, yakni sekitar 30\% (Benowitz \& Brunetta, 2016). Terdapat hubungan kuat antara merokok dengan kanker pada kepala, leher, hati, kandung kemih, leher rahim, kerongkongan, dan usus besar (United States Department of Health and Human Services, 2014). Selain kanker, penggunaan rokok juga berkaitan kuat dengan penyakit yang berkaitan dengan jantung dan pembuluh darah (Messner \& Bernhard, 2014), penyakit pernafasan (Tantisuwat \& Thaveeratitham, 2014; Vassallo \& Ryu, 2018), serta menyebabkan beberapa kelainan pada sistem reproduksi (Dechanet et al., 2011; Kovac, Khanna, \& Lipshultz, 2015).

Nikotin merupakan penyebab utama kecanduan tembakau dan pendorong utama perilaku merokok (Benowitz, 2009). Penggunaan nikotin ditandai dengan pelepasan dopamin yang menimbulkan perasaan menyenangkan bagi pengguna rokok dan menimbulkan kecanduan (Nestler, 2005). Bagi perokok, Nikotin dirasakan dapat mengurangi rasa stress, kegelisahan, meningkatkan konsentrasi, dan bahkan meningkatkan kinerja (Hughes \& Hatsukami, 1986). Pada saat yang sama, pengguna rokok juga mengaitkan efek yang ditimbulkan oleh Nikotin pada banyak situasi (Rose, Behm, \& Levin, 1993). Perokok memiliki argumen bahwa merokok harus dilakukan dalam situasi tertentu seperti setelah makan, dengan secangkir kopi, atau pada saat bertemu dengan teman-teman. Hubungan antara merokok dengan situasi yang berulang-ulang menjadi penyebab perokok sulit untuk berhenti merokok (Naqvi, Rudrauf, Damasio, \& Bechara, 2007)

Istilah smoking behaviour atau kebiasaan merokok mengacu pada perilaku merokok aktif, yaitu menghirup asap tembakau secara sengaja. Merokok merupakan bentuk konsumsi tembakau yang paling umum dan sering diasosiasikan dengan penyebab munculnya berbagai penyakit kronis seperti stroke dan tuberkulosis (Davies et al., 2006; Leung et al., 2003; Newcomb \& Carbone, 1992; Shah \& Cole, 2010). Selain menjadi sumber berbagai penyakit, kebiasaan merokok juga sering diasosiasikan dengan pelemahan atau penurunan psikis seseorang, termasuk kemampuan kognitif (Carmelli et al., 1999; Cervilla et al., 2000)..

Roy (2013) mendefinisikan kemampuan kognitif sebagai suatu fungsi dari otak yang memproses bagaimana orang menilai sesuatu, mengingat, berpikir, membuat keputusan, dan menyelesaikan masalah. Untuk mengukur kemampuan kognitif seseorang, bisa dilakukan berbagai tes dengan memberikan pertanyaan yang meliputi kemampuan visual, mengingat, 
dan logika ataupun menggunakan tes Intelligent Quotient (IQ) yang sering dijadikan proksi dari kemampuan kognitif seseorang (Farias et al., 2008; Mohn, Sundet, \& Rund, 2014). Tes lain yang sering digunakan untuk mengukur kemampuan kognitif seseorang ialah tes Raven Progressive Matrices (RPM), RPM merupakan sebuah tes non-verbal yang berisikan pertanyaanpertanyaan berupa melanjutkan pola geometri untuk mengukur fluid intelligence seseorang (Kaplan \& Saccuzzo, 2012). RPM merupakan tes yang paling umum digunakan untuk mengukur kemampuan kognitif seseorang yang berusia 5 tahun ke atas (Boyede, Lesi, Ezeaka, \& Umeh, 2013; Goharpey, Crewther, \& Crewther, 2013; Skuy et al., 2002).

Pada umumnya, fungsi kognitif seseorang akan terus berubah sepanjang hidupnya dimana akan berkembang dan mencapai puncaknya pada usia 20-30 tahun dan akan mengalami penurunan ketika mencapai usia yang lebih tua (Nouchi \& Kawashima, 2014). Selain penurunan natural akibat penuaan, kemampuan kognitif dapat dipengaruhi berbagai hal, salah satunya ialah faktor sosioekonomi. Berbagai penelitian seperti Duncan \& Magnuson (2012) dan Shih et al., (2011) menemukan bahwa pendidikan orang tua yang tinggi ataupun bertempat tinggal di wilayah dengan kesempatan yang lebih banyak dan status ekonomi yang lebih baik dapat diasosiasikan dengan kemampuan kognitif yang lebih tinggi.

Penggunaan rokok juga berpengaruh pada penurunan kognitif pada manusia yang dikaitkan dengan penurunan lebih cepat pada memori verbal dan kemampuan visual. Di Inggris Raya, efek penurunan kognitif yang lebih besar terjadi pada pengguna rokok yang mengkonsumsi rokok lebih dari 20 rokok per hari (Richards et al., 2003). Penurunan kognitif dikaitan dengan umur dan status pendidikan pada dua kelompok yang berbeda, yaitu kelompok perokok dan tidak perokok. Hasilnya, kelompok perokok memiliki gangguan kognitif yang signifikan dengan metode Attention-Switching Task (Bashir et al., 2017). Attention-Switching Task merupakan salah satu permainan pelatihan otak untuk mengukur fungsi kognitif seseorang (Al-Thaqib et al., 2018). Hubungan yang kuat ditemukan antara terus merokok dan penurunan kognitif, seiring bertambahnya usia pengguna rokok (Stewart, Deary, Fowkes, \& Price, 2006). Penggunaan rokok dari usia muda menyebabkan penurunan kognitif yang lebih buruk (Fried, Watkinson, \& Gray, 2006). Hal ini dikaitkan dengan IQ anak yang lebih rendah dan menjadi lebih buruk jika terus merokok hingga akhir hidup (Corley et al., 2012). Selain itu, efek terburuk kerusakan fungsi kognitif akibat merokok dari usia muda juga ditemukan pada pasien skizofrenia (Zhang et al., 2012).

\section{METODE PENELITIAN}

Data yang digunakan dalam penelitian ini berasal dari Indonesian Family life Survey (IFLS) yang merupakan survei yang dilakukan oleh RAND Corporation yang berfokus pada kesehatan dan sosioekonomi dari 80.000 individu dan 10.000 rumah tangga di 13 provinsi di Indonesia (Strauss, Witoelar, \& Sikoki, 2016). Untuk menjawab pertanyaan penelitian yang ada, memanfaatkan bentuk longitudinal dari IFLS, sampel yang digunakan pada penelitian ini adalah 7.970 orang yang berusia 15 tahun ke atas pada tahun 2007 (IFLS 4) lalu diikuti dan dibuat ke dalam bentuk panel dengan data individu yang sama pada tahun 2014 (IFLS 5). Data yang digunakan antara lain ialah data tingkat kognitif seseorang serta karakteristik sosioekonomi baik di tingkat individu dan rumah tangga. Metode analisis data yang digunakan dalam penelitian ini ialah regresi data panel dengan model random effect. Regresi data panel yang merupakan kombinasi dari data cross-section dan time-series yang dipercaya dapat memberikan estimasi yang lebih robust dikarenakan memberikan penjelasan yang lebih baik jika dibandingkan dengan hanya crosssection atau time-series (Hsiao, 2003).

Model yang digunakan dalam penelitian ini mengacu pada Corley et al., (2012) \& Sabia et al., (2008), bahwa tingkat kognitif seseorang dipengaruhi oleh status merokok seseorang, serta mengontrol variabel status sosioekonomi (SES) pada tingkat individu dan rumah tangga sehingga menghasilkan estimasi yang robust. Jika ditulis ke dalam model matematis menjadi,

Cognitive Level $=f($ smoking_status,SES $)$ 
Indikator yang digunakan untuk mengukur tingkat kognitif seseorang diambil dari bagian pengukuran perkembangan logika IFLS (Buku EK2) dimana responden yang berusia $15 \mathrm{ke}$ atas diberikan 22 pertanyaan teka-teki logika berupa melanjutkan pola gambar dan matematika.
Selanjutnya, skor diubah ke dalam bentuk z-score agar distribusi data menjadi normal. Model ini bisa dikembangkan dan disesuaikan dengan data kontrol sosioekonomi lainnya yang tersedia di IFLS 5 dan IFLS 4 menjadi:

Cognitive Level $=f\left(\begin{array}{c}\text { smoking_status, gender, age, } \\ \text { education, } \text { workingstatusmaritalstatus, }, \text { urban, expenditure, }\end{array}\right)$

Untuk mengukur status ekonomi seseorang, peneliti memilih untuk menggunakan variabel pengeluaran per kapita dibandingkan alternatif lain, yakni pendapatan dan indeks kekayaan relatif berdasarkan kepemilikan aset dikarenakan masalah reliabilitas dan validitas yang lebih mungkin terjadi. Maka dari itu, persamaan (2) dapat ditulis ke dalam model ekonometrik menjadi,

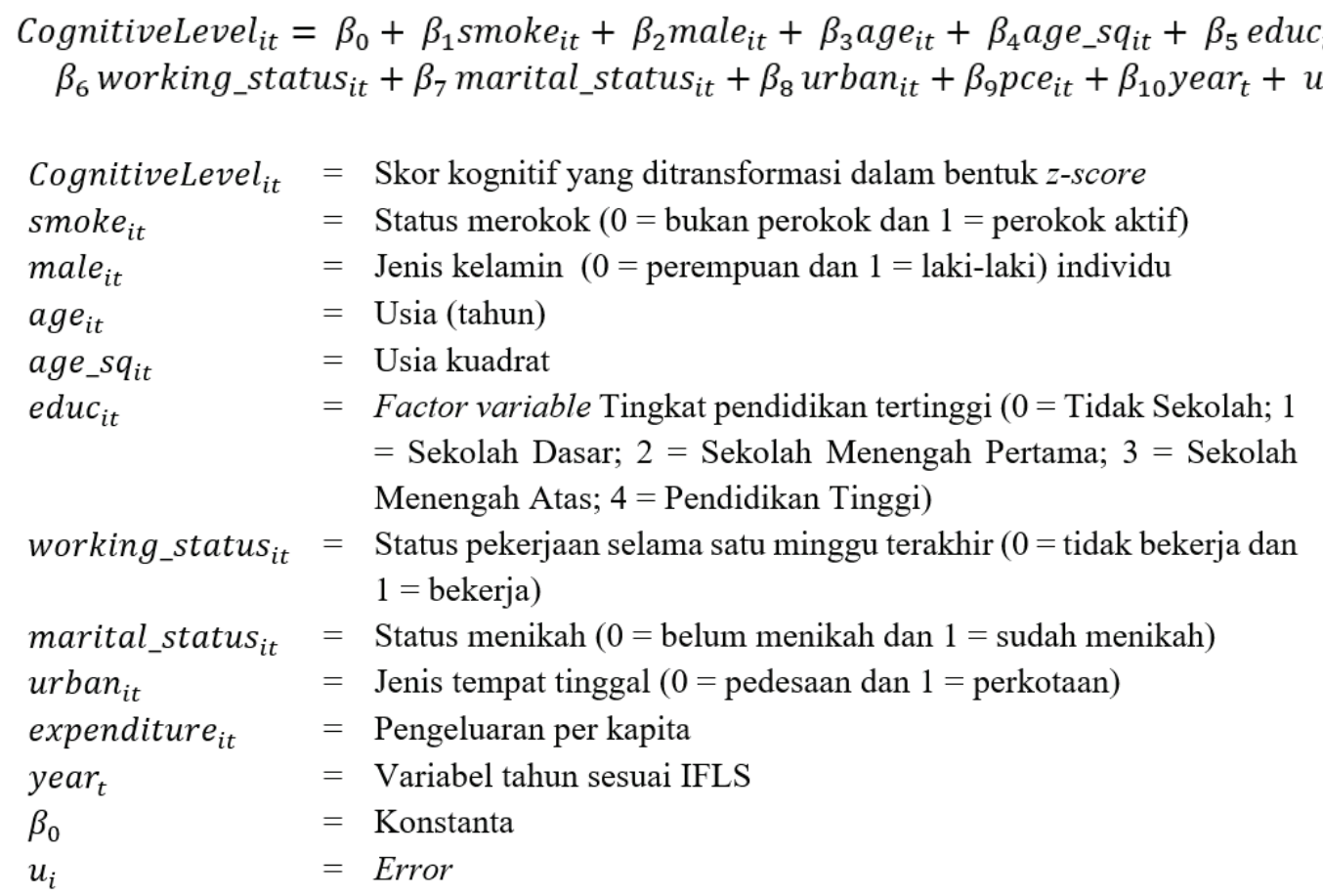

Variabel yang telah disampaikan di atas diambil dari berbagai buku/seksi dalam IFLS dengan sumber disampaikan dalam Tabel 1 di bawah.

Tabel 1. Referensi BUKU IFLS

\begin{tabular}{ll}
\hline Variabel & Book (seksi) \\
\hline CognitiveLevel & Buku EK2 pertanyaan EK0 sampai dengan EK22. \\
Smoke & Buku 3B seksi KM (kebiasaan merokok) pertanyaan KM01a dan KM04. \\
Male & Buku EK2 pertanyaan COV5. \\
Age & Buku EK2 pertanyaan COV3. \\
Educ & Buku 3A seksi DL (pendidikan) pertanyaan DL06. \\
Work & Buku 3A seksi TK (Tenaga Kerja) pertanyaan TK01a. \\
Married & Buku 3B seksi COV pertanyaan COV4. \\
Urban & Buku K seksi SC (Keterangan Sampling) pertanyaan SC05. \\
Expenditure & Buku PCE Nom \\
\hline
\end{tabular}

Sumber: Kuesioner IFLS 


\section{HASIL DAN PEMBAHASAN}

Dilihat dari tabel ringkasan statistik di bawah, sampel yang digunakan dalam penelitian ini berjumlah 7.970 individu berusia 15 tahun ke atas pada tahun 2007 yang 44\% diantaranya berjenis kelamin laki-laki dan $56 \%$ perempuan. Tabel 2 menunjukkan bahwa 27\% dari sampel yang digunakan merupakan seorang perokok yang jika diklasifikasikan berdasarkan tingkat adiksinya menjadi $22 \%$ perokok ringan, $5 \%$ perokok menengah, dan $1 \%$ perokok berat. Menelusuri data individu yang sama pada tahun 2014, terdapat peningkatan jumlah perokok menjadi $32 \%$ yang terdiri dari $20 \%$ perokok ringan, $10 \%$ perokok menengah, dan $2 \%$ perokok berat. Hal ini diakibatkan adanya individu yang pada tahun 2007 belum merokok lalu terdata menjadi perokok pada tahun 2014 dan adanya peningkatan adiksi (yang sebelumnya hanya perokok ringan menjadi perokok menengah atau berat).

Tabel 2. Ringkasan Statistik di 7.970 Individu pada IFLS 4 dan 5

\begin{tabular}{lllll}
\hline \multirow{2}{*}{ Variabel } & \multicolumn{2}{l}{ IFLS 4 (2007) } & \multicolumn{2}{l}{ IFLS $5(2014)$} \\
Skor Kognitif & Mean & SD & Mean & SD \\
Skor Kognitif (Distandardisasi dengan z-score) & 35,35 & 13,65 & 32,11 & 13,69 \\
Bukan Perokok & 0,09 & 0,89 & 0,31 & 0,86 \\
Perokok Ringan (1-15 batang rokok/hari) & 0,73 & 0,45 & 0,68 & 0,47 \\
Perokok Menengah (16-24 batang rokok/hari) & 0,22 & 0,41 & 0,20 & 0,40 \\
Perokok Berat (>24 batang rokok/hari) & 0,05 & 0,21 & 0,10 & 0,30 \\
Laki-laki & 0,01 & 0,10 & 0,02 & 0,14 \\
Usia & 0,44 & 0,50 & 0,44 & 0,50 \\
Usia kuadrat & 23,05 & 4,85 & 29,94 & 4,85 \\
Tidak Bersekolah & 554,91 & 225,84 & 920,17 & 292,09 \\
Sekolah Dasar & 0,01 & 0,11 & 0,01 & 0,10 \\
Sekolah Menengah Pertama & 0,24 & 0,43 & 0,22 & 0,42 \\
Sekolah Menengah Atas & 0,25 & 0,44 & 0,23 & 0,42 \\
Pendidikan Tinggi & 0,39 & 0,49 & 0,36 & 0,48 \\
Bekerja & 0,10 & 0,30 & 0,17 & 0,38 \\
Menikah & 0,55 & 0,50 & 0,72 & 0,45 \\
Tinggal di wilayah perkotaan & 0,51 & 0,50 & 0,77 & 0,42 \\
Pengeluaran per kapita (log) & 0,51 & 0,50 & 0,59 & 0,49 \\
\hline
\end{tabular}

Sumber: IFLS 4 dan 5, diolah

Untuk indikator skor kognitif yang dihitung dari tes Raven's Progressive Matrices (RPM) yang diubah kedalam skala $0-100$, rata-rata nilai skor sampel pada tahun 2007 ialah 35,35 dengan nilai terendah 0 dan nilai tertinggi sebesar 59,59 (standar deviasi $=13,64)$. Pada tahun 2014, terjadi penurunan rata-rata skor kognitif sampel menjadi 32,1 dengan nilai terendah yang sama dan tertinggi yang sama (standar deviasi $=$ 13,69). Nilai standar deviasi yang cukup tinggi menunjukkan persebaran data yang tinggi (jauh dari rata-rata).
Untuk menjawab pertanyaan penelitian yang sudah dibahas dalam bagian sebelumnya, metode regresi data panel digunakan untuk melihat bagaimana pengaruh variabel interest, yakni variabel dummy merupakan seorang perokok dan juga mengontrol karakteristik sosio-ekonomi dan pengaruh tahun. 
Tabel 3. Hasil Regresi Panel

\begin{tabular}{ll}
\hline Variabel & $\begin{array}{l}\text { Model 1 } \quad \text { Model 2 } \\
\text { (dependen }=\text { skor } \\
\text { kognitif) }\end{array}$
\end{tabular}

\begin{tabular}{lll}
$\begin{array}{l}\text { Status Merokok } \\
\text { (reference group = bukan } \\
\text { perokok) }\end{array}$ & & \\
Perokok aktif & $-0,831^{* * *}$ & $-0,103^{* * *}$ \\
& $(0,0163)$ & $(0,0209)$ \\
Constant & $-98,53^{* * *}$ & $-102,6^{* * *}$ \\
& $(3,128)$ & $(4,751)$ \\
& & \\
Kontrol Karakteristik & NO & YES \\
Sosio-ekonomi & & \\
Kontrol Tahun & YES & YES \\
Jumlah Observasi & 15.940 & 15.940 \\
Jumlah Grup Panel & 7.970 & 7.970 \\
\hline
\end{tabular}

Sumber: IFLS 4 dan 5, diolah

Tabel 3 menunjukkan hasil regresi data panel terkait pengaruh dari status merokok terhadap tingkat kognitif. Hasil regresi pada model 1 menunjukkan ada pengaruh negatif dari rokok terhadap tingkat kognitif seseorang dimana dengan tingkat signifikasi sebesar $1 \%$, menjadi seorang perokok aktif berasosiasi dengan skor kogntif yang lebih rendah sebesar 0,831 standar deviasi (SD) dibandingkan dengan bukan perokok. Bahkan dengan mengontrol karakteristik sosio-ekonomi, atau dengan kata lain membandingkan individu dengan status ekonomi, usia, pendidikan dan karakteristik sosioekonomi lain yang sama, hubungan negatif yang sama tetap ditemukan dan signifikan secara statistik. Hal ini ditunjukkan pada model 2 yakni seorang perokok aktif berasosiasi dengan skor kognitif yang lebih rendah sebesar 0,103 SD lebih rendah dibandingkan dengan bukan perokok. Hal ini sejalan dengan penelitian Corley et al., (2012), Havermans et al., (2003), Richards et al., (2003), dan Sabia et al., (2008) bahwa merokok meningkatkan resiko masalah paru-paru dan kesehatan lainnya dan dicerminkan dalam penurunan fungsi kognitif seseorang.

Peneliti berusaha menulusuri lebih lanjut bagaimana besaran dari pengaruh status merokok terhadap skor kognitif seseorang berbeda jika diklasifikasi menjadi kelompok-kelompok lain yang lebih spesifik berdasarkan tingkat adiksinya. Peneliti membagi status merokok menjadi 4 kelompok, 1) bukan perokok, 2) perokok ringan yang mengonsumsi 1-15 batang rokok per hari, 3 ) perokok menengah yang mengonsumsi 16-24 batang rokok per hari, dan 4) perokok berat yang mengonsumsi lebih dari 24 batang rokok per hari (Friend \& Pagano, 2005).

Ketika pengaruh dari status merokok terhadap tingkat kognitif sesorang distratifikasi berdasarkan tingkat adiksinya, Tabel 4 menunjukkan bahwa pada tingkat signifikansi $1 \%$ dan dengan mengontrol karakteristik sosioekonomi dan pengaruh tren, semakin tinggi tingkat adiksi terhadap rokok, semakin besar pengaruhnya terhadap penurunan skor kognitif. Perokok ringan, menengah, dan berat secara berurutan berasosiasi dengan skor kognitif yang lebih rendah sebesar 0,0892, 0,115, dan 0,253 SD dibandingkan dengan bukan perokok.

Tabel 4. Hasil regresi panel (berdasarkan tingkat adiksi)

\begin{tabular}{|c|c|c|}
\hline \multirow{2}{*}{ Variabel } & Model 1 & Model 2 \\
\hline & \multicolumn{2}{|c|}{ (dependen = skor kognitif) } \\
\hline \multicolumn{3}{|c|}{$\begin{array}{l}\text { Status Merokok } \\
\text { (Berdasarkan tingkat } \\
\text { adiksi) } \\
\text { (reference group = bukan } \\
\text { perokok) }\end{array}$} \\
\hline \multirow[t]{2}{*}{ Perokok ringan } & $-0,0771^{* * *}$ & $-0,0892^{* * *}$ \\
\hline & $(0,0180)$ & $(0,0220)$ \\
\hline \multirow[t]{2}{*}{ Perokok menengah } & $-0,0708^{* * *}$ & $-0,115^{* * *}$ \\
\hline & $(0,0269)$ & $(0,0293)$ \\
\hline \multirow[t]{2}{*}{ Perokok berat } & $-0,2332^{* * *}$ & $-0,253^{* * *}$ \\
\hline & $(0,0589)$ & $(0,0590)$ \\
\hline \multirow[t]{2}{*}{ Constant } & $-98,80^{\star * *}$ & $-102,5^{* * *}$ \\
\hline & $(3,156)$ & $(4,752)$ \\
\hline $\begin{array}{l}\text { Kontrol Karakteristik } \\
\text { Sosioekonomi }\end{array}$ & NO & YES \\
\hline Kontrol Tahun & YES & YES \\
\hline Jumlah Observasi & 15.940 & 15.940 \\
\hline Jumlah Grup Panel & 7.970 & 7.970 \\
\hline
\end{tabular}

Sumber: IFLS 4 dan 5, diolah 
Hasil estimasi di atas menunjukkan adanya hubungan yang negatif antara status merokok dan tingkat adiksi rokok terhadap kemampuan kognitif seseorang. Ditambah lagi, melihat pola pada 7.970 sampel individu yang sama pada tahun 2007 dan 2014, banyak dari yang sebelumnya tidak merokok lalu menjadi perokok, dan orang yang pada tahun 2007 sudah merokok memiliki kecenderungan untuk meningkatan konsumsi rokoknya pada tahun 2014. Hal ini menjustifikasi perlunya kebijakan serta penegasan peraturan yang sudah ada sebelumnya dalam mengurangi konsumsi rokok di masyarakat. Nyatanya, akses terhadap rokok masih terhitung mudah terutama bagi masyarakat di bawah umur yang merupakan kelompok konsumen rokok terbesar di Indonesia. Hal ini disebabkan oleh banyaknya penjual rokok berupa kios kecil dan supermarket yang tersedia di berbagai tempat termasuk dekat dari sekolah (Astuti, Mulyawan, Sebayang, Kurniasari, \& Freeman, 2019), kemampuan untuk pembelian secara satuan (Rong, Marquez, Abdillah, Xiao, \& Yang, 2018), serta belum adanya peraturan atau penegasan tertentu dari pemerintah yang melarang konsumsi rokok bagi masyarakat di bawah umur. Studi dari Azagba et al., (2020) dan Thrasher et al., (2009) juga menunjukkan bahwa faktor-faktor tersebut mendorong konsumsi rokok bagi masyarakat di bawah umur.

Selain berpengaruh negatif terhadap penurunan tingkat kognitif seseorang secara langsung, konsumsi rokok seseorang juga dapat mempengaruhi tingkat kognitif orang lain, dalam kasus ini ialah anggota lain dalam suatu rumah tangga. Julvez et al., (2007) dan Rahu et al., (2010) menemukan bahwa anak yang terlahir dari ibu yang merokok pada masa sebelum kelahirannya berasosiasi dengan tingkat kognitif yang lebih rendah. Selain itu, konsumsi rokok dengan jumlah banyak tiap harinya tentu membutuhkan uang yang tidak sedikit dan uang itu bisa saja seharusnya digunakan untuk keperluan rumah tangga yang lebih penting seperti pendidikan dan kesehatan. Wang et al., (2006) dengan studi kasus rumah tangga di pedesaan di Cina dan Masaud et al., (2020) menunjukkan bahwa konsumsi rokok pada suatu rumah tangga berpengaruh terhadap pengurangan pengeluaran pada kelompok investasi kapital (pendidikan dan kesehatan). Hal ini sungguh berbahaya terutama bagi rumah tangga dengan status ekonomi yang rendah.

Gambar 1. Rata-rata proporsi pengeluaran alkohol dan tembakau terhadap pengeluaran rumah tangga berdasarkan kuintil (\%)

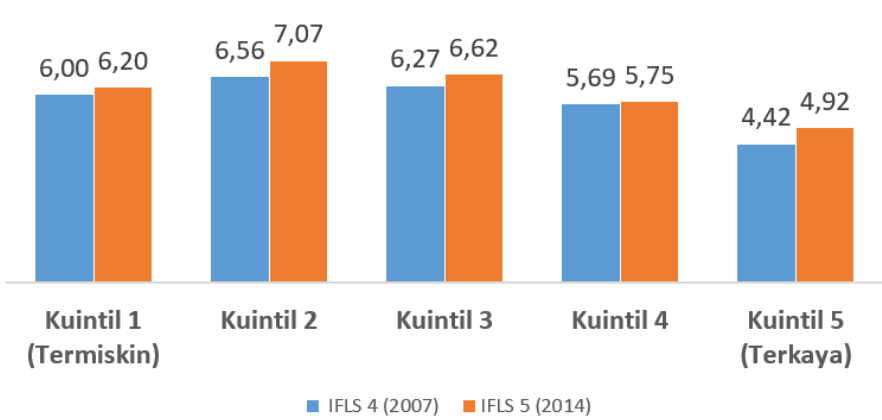

Sumber: IFLS 4 dan 5, diolah

Berdasarkan data IFLS 4 dan 5 yang ditunjukkan pada Figur 1, nyatanya rumah tangga yang berasal dari kelompok status ekonomi $40 \%$ terbawah (kuintil 1 dan 2), memiliki rata-rata proposi pengeluaran alkohol dan tembakau terhadap pengeluaran rumah tangga yang lebih tinggi dibandingkan dengan rumah tangga yang berasal dari kelompok status ekonomi $20 \%$ teratas (kuintil 5) dan terjadi peningkatan konsumsi dari tahun 2007 ke tahun 2014. Hal ini nantinya akan berpengaruh negatif, terutama bagi rumah tangga miskin dikarenakan akan memiliki kapabilitas uang yang lebih sedikit untuk kebutuhan yang vital (pendidikan dan kesehatan) yang tentunya akan mempengaruhi produktivitas seseorang.

Mengetahui jumlah perokok di bawah umur yang sangat tinggi, salah satu kebijakan yang dapat dilakukan oleh pemerintah Indonesia ialah pelarangan konsumsi rokok bagi masyakarat di bawah umur sebagaimana yang telah diberlakukan di Amerika Serikat (DiFranza, Savageau, \& Fletcher, 2009) dan India (Chadda \& Sengupta, 2003; Jandoo \& Mehrotra, 2008) yang berhasil mengurangi konsumsi rokok di kalangan masyarakat di bawah umur. Selain itu, upaya lain seperti pembatasan iklan rokok di berbagai jenis media serta peningkatan pemberian informasi terkait konsekuensi merokok terhadap kesehatan seperti yang diberlakukan di Korea Selatan juga diperlukan (Kim \& Seldon, 2004). Peningkatan cukai rokok juga merupakan hal yang esensial sebagai upaya dalam pengurangan konsumsi 
rokok secara umum (Nargis, Hussain, Goodchild, Quah, \& Fong, 2019; Yorozu \& Zhou, 2002).

\section{KESIMPULAN DAN REKOMENDASI}

Merokok merupakan salah satu penyebab masalah kesehatan terbesar di dunia, termasuk di Indonesia, karena sering diasosiasikan dengan munculnya masalah kesehatan pada tubuh, salah satunya adalah penurunan fungsi kognitif otak. Dengan menggunakan data dari Indonesian Family Life Survey (IFLS) tahun 2007 (IFLS 4) dan 2014 (IFLS 5), penelitian ini menggunakan metode regresi data panel dengan model random effect untuk melihat hubungan antara status merokok terhadap kemampuan kognitif seseorang dengan mengontrol faktor sosioekonomi baik tingkat individu maupun rumah tangga serta pengaruh tren. Hasil estimasi menunjukkan bahwa menjadi seorang perokok berasosiasi dengan tingkat kognitif yang lebih rendah 0.1 Standar Deviasi (SD) dibandingkan dengan bukan perokok. Ketika status merokok dipecah berdasarkan tingkat adiksi, yakni perokok ringan, menengah, dan berat, efek penurunan tingkat kognitif semakin besar secara berurutan 0,08 , 0,11 , dan 0,25 SD. Penemuan ini sejalan dengan hasil yang ditemukan oleh Havermans et al., (2003), Karama et al., (2015), dan Sabia et al., (2008) dan mengindikasikan bahwa kebiasaan merokok memang memiliki pengaruh negatif terhadap kemampuan kognitif seseorang.

Dari penemuan di atas, sangat diperlukan adanya kebijakan pemerintah dalam upaya pengurangan konsumsi rokok di masyarakat, terutama bagi masyarakat di bawah umur yang merupakan kelompok perokok terbanyak. Upaya yang sudah dilakukan di negara lain seperti pembatasan iklan rokok di berbagai media, pelarangan konsumsi rokok bagi masyarakat di bawah umur, dan peningkatan cukai rokok merupakan hal yang esensial dalam mengurangi konsumsi rokok di masyarakat. Rekomendasi yang bisa diberikan kepada masyarakat ialah untuk mengubah pola hidup menjadi lebih sehat yakni dengan mengurangi atau menjauhi konsumsi rokok karena dapat memberikan dampak negatif bagi tubuh, termasuk penurunan kemampuan kognitif yang bisa mengakibatkan kerugian ekonomi baik pada tingkat individu maupun pada skala makro.

\section{DAFTAR PUSTAKA}

Al-Thaqib, A., Al-Sultan, F., Al-Zahrani, A., Al-Kahtani, F., Al-Regaiey, K., Iqbal, M., \& Bashir, S. (2018). Brain Training Games Enhance Cognitive Function in Healthy Subjects. Medical Science Monitor Basic Research, 24, 63-69. https://doi. org $/ 10.12659 / \mathrm{msmbr} .909022$

Astuti, P. A. S., Mulyawan, K. H., Sebayang, S. K., Kurniasari, N. M. D., \& Freeman, B. (2019). Cigarette retailer density around schools and neighbourhoods in Bali, Indonesia: A GIS mapping. Tobacco Induced Diseases, 17(July), 1-12. https://doi.org/10.18332/ tid/110004

Azagba, S., Shan, L., Manzione, L. C., Latham, K., Rogers, C., \& Qeadan, F. (2020). Single cigarette purchasers among adult U.S. smokers. Preventive Medicine Reports, 17(January), 101055. https://doi. org/10.1016/j.pmedr.2020.101055

Bashir, S., Alghamd, F., Alhussien, A., Alohali, M., Alatawi, A., Almusned, T., \& Habib, S. S. (2017). Effect of Smoking on Cognitive Functioning in Young Saudi Adults. Medical Science Monitor Basic Research, 23, 31-35. https://doi.org/10.12659/msmbr.902385

Benowitz, N. L. (2009). Pharmacology of Nicotine: Addiction, Smoking-Induced Disease, and Therapeutics. Annual Review of Pharmacology and Toxicology, 49, 57-71. https://doi.org/10.1146/annurev. pharmtox.48.113006.094742

Benowitz, N. L. (2010). Nicotine addiction. New England Journal of Medicine, 13(12), 1240-1249. https://doi.org/10.1056/ NEJMra0809890

Benowitz, N. L., \& Brunetta, P. G. (2016). Smoking Hazards and Cessation. In Murray and Nadel's Textbook of Respiratory Medicine (pp. 807-821). https://doi.org/10.1016/ b978-1-4557-3383-5.00046-4 
Bergen, A. W., \& Caporaso, N. (1999). Cigarette smoking. Journal of the National Cancer Institute, 91(16), 11365-11375. https://doi. org/10.1093/jnci/91.16.1365

Bloom, D. E., Canning, D., \& Sevilla, J. (2004). The effect of health on economic growth: A production function approach. World Development, 32(1), 1-13. https://doi. org/10.1016/j.worlddev.2003.07.002

Boyede, G. O., Lesi, F. E. A., Ezeaka, V. C., \& Umeh, C. S. (2013). Impact of sociodemographic factors on cognitive function in school-aged HIV-infected Nigerian children. HIV/AIDS - Research and Palliative Care, 5, 145-152. https://doi. org/10.2147/HIV.S43260

Carmelli, D., Swan, G. E., Reed, T., Schellenberg, G. D., \& Christian, J. C. (1999). The effect of apolipoprotein $\mathrm{E} \varepsilon 4$ in the relationships of smoking and drinking to cognitive function. Neuroepidemiology, 18(3), 125-133. https:// doi.org/10.1159/000026204

Cervilla, J. A., Prince, M., \& Mann, A. (2000). Smoking, drinking, and incident cognitive impairment: A cohort community based study included in the Gospel Oak project. Journal of Neurology Neurosurgery and Psychiatry, 68(5), 622-626. https://doi. org/10.1136/jnnp.68.5.622

Chadda, R., \& Sengupta, S. (2003). Tobacco use by Indian adolescents. Tobacco Induced Diseases, 1(1), 8. https://doi. org/10.1186/1617-9625-1-8

Corley, J., Gow, A. J., Starr, J. M., \& Deary, I. J. (2012). Smoking, childhood IQ, and cognitive function in old age. Journal of Psychosomatic Research, 73(2), 132-138. https://doi. org/10.1016/j.jpsychores.2012.03.006

Davies, P.D. O., Yew, W. W., Ganguly, D., Davidow, A. L., Reichman, L. B., Dheda, K., \& Rook, G. A. (2006). Smoking and tuberculosis: The epidemiological association and immunopathogenesis. Transactions of the Royal Society of Tropical Medicine and Hygiene, 100(4), 291-298. https://doi. org/10.1016/j.trstmh.2005.06.034
Dechanet, C., Anahory, T., Mathieu Daude, J. C., Quantin, X., Reyftmann, L., Hamamah, S., ... Dechaud, H. (2011). Effects of cigarette smoking on reproduction. Human Reproduction Update, 17(1), 76-95. https:// doi.org/10.1093/humupd/dmq033

DiFranza, J. R., Savageau, J. A., \& Fletcher, K. E. (2009). Enforcement of underage sales laws as a predictor of daily smoking among adolescents - A national study. BMC Public Health, 9, 1-7. https://doi.org/10.1186/14712458-9-107

Doll, R., Peto, R., Boreham, J., \& Sutherland, I. (2004). Mortality in relation to smoking: 50 Years' observations on male British doctors. British Medical Journal, 328(7455), 1519. https://doi.org/10.1136/bmj.38142.554479. ae

Duncan, G. J., \& Magnuson, K. (2012). Socioeconomic status and cognitive functioning: Moving from correlation to causation. Wiley Interdisciplinary Reviews: Cognitive Science, 3(3), 377-386. https:// doi.org/10.1002/wcs.1176

Farias, S. T., Mungas, D., Reed, B. R., CahnWeiner, D., Jagust, W., Baynes, K., \& DeCarli, C. (2008). The Measurement of Everyday Cognition (ECog): Scale Development and Psychometric Properties. Neuropsychology, 22(4), 531-544. https:// doi.org/10.1037/0894-4105.22.4.531

Fried, P. A., Watkinson, B., \& Gray, R. (2006). Neurocognitive consequences of cigarette smoking in young adults-a comparison with pre-drug performance. Neurotoxicology and Teratology, 28(4), 517-525. https://doi. org/10.1016/j.ntt.2006.06.003

Friend, K. B., \& Pagano, M. E. (2005). Changes in cigarette consumption and drinking outcomes: Findings from Project MATCH. Journal of Substance Abuse Treatment, 29(3), 221-229. https://doi.org/10.1016/j. jsat.2005.07.001 
Goharpey, N., Crewther, D. P., \& Crewther, S. G. (2013). Problem solving ability in children with intellectual disability as measured by the Raven's Colored Progressive Matrices. Research in Developmental Disabilities, 34(12), 4366-4374. https://doi. org/10.1016/j.ridd.2013.09.013

Goodchild, M., Nargis, N., \& D'Espaignet, E. T. (2018). Global economic cost of smokingattributable diseases. Tobacco Control, 27(1), 58-64. https://doi.org/10.1136/ tobaccocontrol-2016-053305

Havermans, R. C., Debaere, S., Smulders, F. T. Y., Wiers, R. W., \& Jansen, A. T. M. (2003). Effect of Cue Exposure, Urge to Smoke, and Nicotine Deprivation on Cognitive Performance in Smokers. Psychology of Addictive Behaviors, 17(4), 336-339. https://doi.org/10.1037/0893-164X.17.4.336

Hsiao, C. (2003). Analysis of panel data. Cambridge University Press.

Hughes, J. R., \& Hatsukami, D. (1986). Signs and Symptoms of Tobacco Withdrawal.Archives of General Psychiatry. https://doi.org/10.1001/ archpsyc. 1986.01800030107013

Jandoo, T., \& Mehrotra, R. (2008). Tobacco control in India: present scenario and challenges ahead. Asian Pacific Journal of Cancer Prevention : APJCP, 9(4), 805-810.

Julvez, J., Ribas-Fitó, N., Torrent, M., Forns, M., Garcia-Esteban, R., \& Sunyer, J. (2007). Maternal smoking habits and cognitive development of children at age 4 years in a population-based birth cohort. International Journal of Epidemiology, 36(4), 825-832. https://doi.org/10.1093/ije/dym107

Kaplan, R. M., \& Saccuzzo, D. P. (2012). Psychological Testing: Principles, Applications, and Issues. Cengage Learning.

Karama, S., Ducharme, S., Corley, J., ChouinardDecorte, F., Starr, J. M., Wardlaw, J. M., ... Deary, I. J. (2015). Cigarette smoking and thinning of the brain's cortex. Molecular Psychiatry, 20(6), 778-785. https://doi. org/10.1038/mp.2014.187
Katadata. (2019). Indonesia, Negara dengan Jumlah Perokok Terbanyak di Asean | Databoks. Retrieved June 17, 2020, from https://databoks.katadata.co.id/ datapublish/2019/05/31/indonesia-negaradengan-jumlah-perokok-terbanyak-di-asean

Kim, S., \& Seldon, B. J. (2004). The demand for cigarettes in the Republic of Korea and implications for government policy to lower cigarette consumption. Contemporary Economic Policy, 22(2), 299-308. https:// doi.org/10.1093/cep/byh021

Kovac, J. R., Khanna, A., \& Lipshultz, L. I. (2015). The effects of cigarette smoking on male fertility. Postgraduate Medicine, 127(3), 338-341. https://doi.org/10.1080/0 0325481.2015 .1015928

Leung, C. C., Yew, W. W., Chan, C. K., Tam, C. M., Lam, C. W., Chang, K. C., ... Law, W. S. (2003). Smoking and tuberculosis in Hong Kong. International Journal of Tuberculosis and Lung Disease, 7(10), 980-986.

Masaud, A. G. A., Chelwa, G., \& van Walbeek, C. (2020). Does tobacco expenditure influence household spending patterns in Ghana?: Evidence from the Ghana 2012/2013 Living Standards Survey. Tobacco Induced Diseases, 18, 1-8. https://doi.org/10.18332/ TID/120936

Messner, B., \& Bernhard, D. (2014). Smoking and cardiovascular disease: Mechanisms of endothelial dysfunction and early atherogenesis. Arteriosclerosis, Thrombosis, and Vascular Biology, 34(3), 509-515.https:// doi.org/10.1161/ATVBAHA.113.300156

Mohn, C., Sundet, K., \& Rund, B. R. (2014). The relationship between IQ and performance on the MATRICS consensus cognitive battery. Schizophrenia Research: Cognition, 1(2), 96-100. https://doi.org/10.1016/j. scog.2014.06.003

Murray, C. J. L., \& Lopez, A. D. (1997). Alternative projections of mortality and disability by cause 1990-2020: Global Burden of Disease Study. Lancet, 349(9064), 1498-1504. https://doi.org/10.1016/S01406736(96)07492-2 
Naqvi, N. H., Rudrauf, D., Damasio, H., \& Bechara, A. (2007). Damage to the insula disrupts addiction to cigarette smoking. Science, 315(5811), 531-534. https://doi. org/10.1126/science. 1135926

Nargis, N., Hussain, A. K. M. G., Goodchild, M., Quah, A. C. K., \& Fong, G. T. (2019). A decade of cigarette taxation in bangladesh: Lessons learnt for tobacco control. Bulletin of the World Health Organization, 97(3), 221-229. https://doi.org/10.2471/ BLT.18.216135

Nestler, E. J. (2005). Is there a common molecular pathway for addiction? Nature Neuroscience, 8(11), 1445-1449. https://doi.org/10.1038/ nn1578

Newcomb, P. A., \& Carbone, P. P. (1992). The health consequences of smoking: Cancer. Medical Clinics of North America, 76(2), 305-331. https://doi.org/10.1016/S00257125(16)30355-8

Nouchi, R., \& Kawashima, R. (2014). Improving Cognitive Function from Children to Old Age: A Systematic Review of Recent Smart Ageing Intervention Studies. Advances in Neuroscience, 2014, 1-15. https://doi. org/10.1155/2014/235479

OECD. (2018). PISA 2018 Country Note. Programme for International Student Assessment (PISA) Result from PISA 2018, $1-10$.

Rahu, K., Rahu, M., Pullmann, H., \& Allik, J. (2010). Effect of birth weight, maternal education and prenatal smoking on offspring intelligence at school age. Early Human Development, 86(8), 493-497. https://doi. org/10.1016/j.earlhumdev.2010.06.010

Richards, M., Jarvis, M. J., Thompson, N., \& Wadsworth, M. E. J. (2003). Cigarette smoking and cognitive decline in midlife: evidence from a prospective birth cohort study. American Journal of Public Health, 93(6), 994-998. Retrieved from http://www.ncbi. nlm.nih.gov/pubmed/12773367\%0Ahttp:// www.pubmedcentral.nih.gov/articlerender. fcgi?artid=PMC1447882
Romer, P. (1994). The origins of endogenous growth. Journal of Economic Perspectives, 8(1), 3-22. https://doi. org/10.4324/9780203443965.ch26

Rong, Z., Marquez, P. V, Abdillah, A., Xiao, H., \& Yang, W. (2018). Cigarette Affordability in Indonesia. World Bank. https://doi. org/10.1596/30027

Rose, J. E., Behm, F. M., \& Levin, E. D. (1993). Role of nicotine dose and sensory cues in the regulation of smoke intake. Pharmacology, Biochemistry and Behavior, 44(4), 891-900. https://doi.org/10.1016/00913057(93)90021-K

Roy, E. (2013). Cognitive Function. In M. D. Gellman \& J. R. Turner (Eds.), Encyclopedia of Behavioral Medicine (pp. 448-449). New York, NY: Springer New York. https://doi. org/10.1007/978-1-4419-1005-9_1117

Sabia, S., Marmot, M., Dufouil, C., \& SinghManoux, A. (2008). Smoking history and cognitive function in middle age from the Whitehall II study. Archives of Internal Medicine, 168(11), 1165-1173. https://doi. org/10.1001/archinte.168.11.1165

Schwab, K. (2019). The Global Competitiveness Report 2019. Retrieved from http:// www 3.we forum.org/docs/WEF TheGlobalCompetitivenessReport2019.pdf

Shah, R. S., \& Cole, J. W. (2010). Smoking and stroke: The more you smoke the more you stroke. Expert Review of Cardiovascular Therapy, 8(7), 917-932. https://doi. org/10.1586/erc. 10.56

Shih, R. A., Ghosh-Dastidar, B., Margolis, K. L., Slaughter, M. E., Jewell, A., Bird, C. E., ... Espeland, M. A. (2011). Neighborhood socioeconomic status and cognitive function in women. American Journal of Public Health, 101(9), 1721-1728. https://doi. org/10.2105/AJPH.2011.300169

Shinton, R., \& Beevers, G. (1989). Metaanalysis of relation between cigarette smoking and stroke. British Medical Journal, 298(6676), 789-794. https://doi. org/10.1136/bmj.298.6676.789 
Skuy, M., Gewer, A., Osrin, Y., Khunou, D., Fridjhon, P., \& Rushton, J. P. (2002). Effects of mediated learning experience on Raven's matrices scores of African and non-African university students in South Africa. Intelligence, 30(3), 221-232. https:// doi.org/10.1016/S0160-2896(01)00085-X

Stewart, M. C. W., Deary, I. J., Fowkes, F. G. R., \& Price, J. F. (2006). Relationship between lifetime smoking, smoking status at older age and human cognitive function. Neuroepidemiology, 26(2), 83-92. https:// doi.org/10.1159/000090253

Strauss, J., Witoelar, F., \& Sikoki, B. (2016). The Fifth Wave of the Indonesia Family Life Survey: Overview and Field Report: Volume 1. The Fifth Wave of the Indonesia Family Life Survey: Overview and Field Report: Volume 1, 1(March). https://doi.org/10.7249/ wr1143.1

Tantisuwat, A., \& Thaveeratitham, P. (2014). Effects of smoking on chest expansion, lung function, and respiratory muscle strength of youths. Journal of Physical Therapy Science, 26(2), 167-170. https:// doi.org/10.1589/jpts.26.167

Thrasher, J. F., Villalobos, V., Dorantes-Alonso, A., Arillo-Santillán, E., Michael Cummings, K., O'Connor, R., \& Fong, G. T. (2009). Does the availability of single cigarettes promote or inhibit cigarette consumption? perceptions, prevalence and correlates of single cigarette use among adult Mexican smokers. Tobacco Control, 18(6), 431-437. https://doi.org/10.1136/tc.2008.029132
United States Department of Health and Human Services. (2014). The Health Consequences of Smoking - 50 Years of Progress A Report of the Surgeon General. A Report of the Surgeon General.

Vassallo, R., \& Ryu, J. H. (2018). SmokingRelated Interstitial Lung Diseases. In Interstitial Lung Disease. https://doi. org/10.1016/B978-0-323-48024-6.00003-3

Wang, H., Sindelar, J. L., \& Busch, S. H. (2006). The impact of tobacco expenditure on household consumption patterns in rural China. Social Science and Medicine, 62(6), 1414-1426. https://doi.org/10.1016/j. socscimed.2005.07.032

WHO. (2020). Tobacco. Retrieved June 15, 2020 , from https://www.who.int/news-room/ fact-sheets/detail/tobacco

World Population Review. (2020). Smoking Rates By Country 2020. Retrieved June 17, 2020, from https://worldpopulationreview.com/ countries/smoking-rates-by-country/

Yorozu, I., \& Zhou, Y. (2002). The demand for cigarettes in Japan: Impact of information dissemination on cigarette consumption. Contemporary Economic Policy, 20(1), 72-82. https://doi.org/10.1093/cep/20.1.72

Zhang, X. Y., Chen, D. C., Xiu, M. H., Haile, C. N., Sun, H., Lu, L., ... Kosten, T. R. (2012). Cigarette smoking and cognitive function in Chinese male schizophrenia: A case-control study. PLoS ONE. https://doi.org/10.1371/ journal.pone. 0036563 